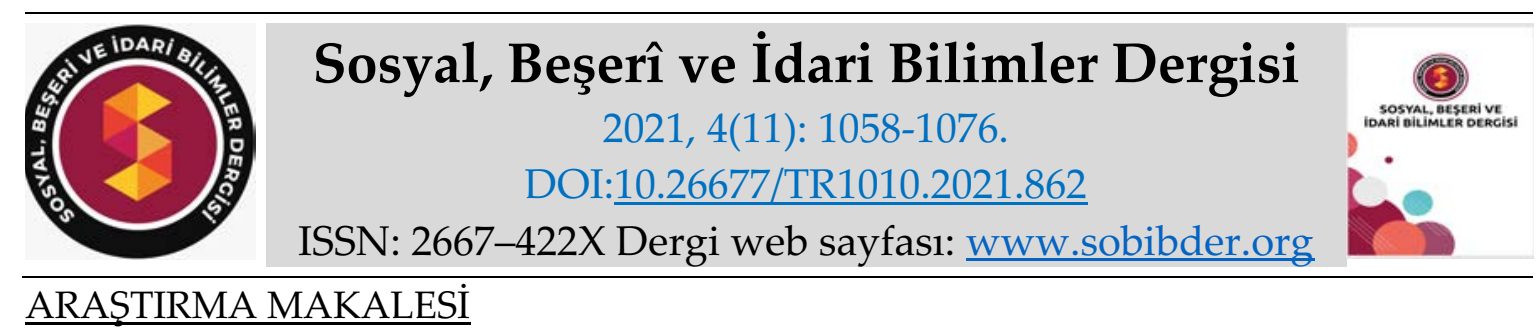

\title{
Gölgede Kalan Bir Sorun Alanı: Kadın Evsizliği
}

Dr. Öğr. Üyesi Ayşin ÇETINKAYA BÜYÜKBODUR, Muş Alparslan Üniversitesi, Sağllk Bilimleri Fakültesi, Muş, e-posta: aysine2@gmail.com

ORCID: https://orcid.org/0000-0002-8042-4174

Dr. Öğr. Üyesi Derya KAYMA, Manisa Celâl Bayar Üniversitesi, Kırkağaç Meslek Yüksekokulu, Manisa, e-posta: deryakayma@gmail.com

ORCID: https://orcid.org/0000-0001-7014-8631

Öz

Evsiz kadınların yaşadıkları sorunların betimlenmesi ve sosyal hizmet odağında çözüm önerilerinin geliştirilmesi amacıyla yapılmış olan bu çalışma nitel araştırma yönteminde durum araştırması olacak şekilde tasarlanmıştır. Veri toplama aracı olarak yarı yapılandırılmış görüşme formu kullanılmıştır. İstanbul ilinde evsiz bireylere hizmet veren barınma merkezlerinde kalan ve sokakta yaşamlarını sürdüren araştırmaya katılmaya gönüllü 22 kadın katılımcı ile 25 Ocak- 6 Şubat 2020 tarihleri arasında yüz yüze görüşmeler yapılmıştır. Veriler fenemonolojik analiz ile çözümlenmiştir. Söylem düzeyinde analiz için veriler döne döne tekrar okunarak araştırmanın amacına uygun olarak katılımcıların evsizlik sürecine geçme nedenleri ve karşılaşabilecek risklere ilişkin düşünceleri iki ayrı bölümde ele alınmıştır. Kadınların söylemlerine ayrıntılı biçimde yer verilmiştir. Araştırmadan elde edilen bulgularda; kadın katılımcılarda evsizliğe neden olan faktörler arasında aile içi sorunlar ve ucuz kiralık konuta erişememe ve işsizlik yer almaktadır. Bununla birlikte kadınların evsiz olmaları durumunda karşılaşabilecekleri önemli risk faktörlerinin açlık ve soğuk, şiddete uğramak ve suç mağduru olma etrafında şekillendiği belirlenmiştir. Kadınları evsizlikten koruyacak sosyal politikaların ve sosyal hizmet uygulamalarının geliştirilmesi önerilmektedir.

Anahtar Kelimeler: Evsizlik Süreci, Kadın Evsizliği, Riskler, Konut İhtiyacı.

Makale Gönderme Tarihi: 19.07.2021

Makale Kabul Tarihi: 02.11.2021

\section{Önerilen Atıf:}

Çetinkaya Büyükbodur, A. ve Kayma, D. (2021). Gölgede Kalan Bir Sorun Alanı: Kadın Evsizliği, Sosyal, Beşeri ve İdari Bilimler Dergisi, 4(11): 1058-1076. 


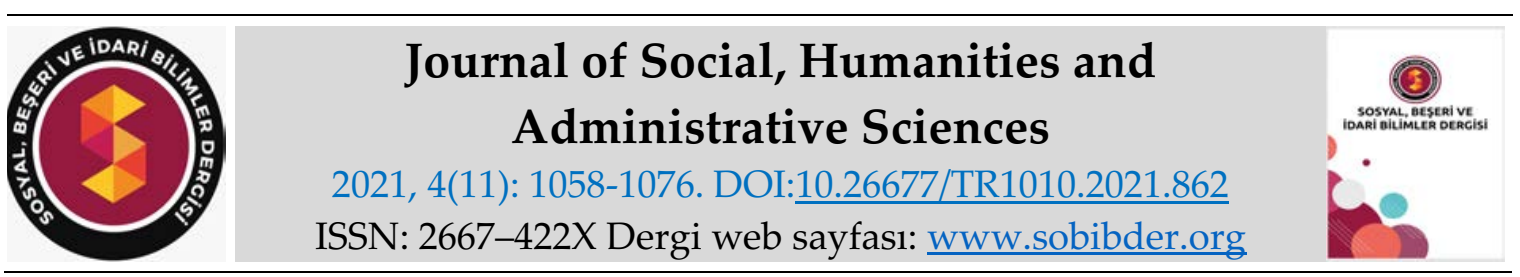

RESEARCH PAPER

\title{
A Shadowed Problem Area: Women Homelessness
}

Assistant Prof. Dr. Ayşin ÇETINKAYA BÜYÜKBODUR, Muş Alparslan University, Faculty of Health Sciences, Muş, e-mail: aysine2@gmail.com

ORCID: https://orcid.org/0000-0002-8042-4174

Assistant Prof. Dr. Derya KAYMA, Manisa Celâl Bayar University, Kırkağaç Vocational School, Manisa, e-mail: deryakayma@gmail.com

ORCID: https://orcid.org/0000-0001-7014-8631

\begin{abstract}
This study, which was conducted to describe the problems experienced by homeless women and to develop solutions in the focus of social work, was designed as a case study in qualitative research method. A semi-structured interview form was used as a data collection tool. It was conducted face-to-face with 22 volunteer female participants living in shelters serving homeless individuals in Istanbul province and living on the streets between January 25 and February 6, 2020. The data were analyzed by phenomenological data analysis. For discourse-level analysis, the data were re-read over and over, and in accordance with the purpose of the research, the reasons for the participants' transition to the homelessness process and their thoughts on the risks they may encounter were discussed in two separate sections. The discourses of women are given in detail. In the findings obtained from the research; Among the factors that cause homelessness among female participants are family problems and inaccessibility to cheap rental housing and unemployment. However, it has been determined that the important risk factors that women may encounter in case of being homeless are shaped around hunger and cold, exposure to violence and being a victim of crime. It is recommended to develop social policies and social work practices that will protect women from homelessness.
\end{abstract}

Keywords: Homelessness Process, Female Homelessness, Risks, Housing Need.

Received: 19.07.2021

Accepted: 02.11.2021

Suggested Citation:

Çetinkaya Büyükbodur, A. and Kayma, D. (2021). A Shadowed Problem Area: Women Homelessness, Journal of Social, Humanities and Administrative Sciences, 4(11): 1058-1076. 


\section{Gíriş}

Evsizlik hem gelişmiş hem de gelişmekte olan ülkelerde, büyük kentsel alanlarda oluşan küresel bir insan hakları sorunudur. Kentlerde nüfus artışı ile birlikte istihdam ve konut sayısındaki yetersizlikler nedeniyle büyük kentler sahip oldukları nüfusun konut ihtiyacını karşılayamaz duruma gelmekte ve yoksullar gecekondu, getto gibi yerlerde yaşamak zorunda kalmaktadırlar (Kaya-Kılıç ve Aslantürk, 2019: 419). Türkiye' de evsiz insanların sayılarına ilişkin istatistiksel verilere ulaşılamamasına rağmen küresel ölçekte bazı ülkelerdeki evsiz sayısına ilişkin veriler bulunmaktadır. ABD'de 2015 yılının Ocak ayında 564.708 insanın geçici barınaklarda, köprü altlarında, çadırlarda ya da terk edilmiş binalarda yaşadıkları belirlenmiştir (AHAR, 2016). Evsizlik sabit ve düzenli kalacak yerin olmaması şeklinde tanımlanırken; kronik evsizlik ise, bir yıl veya daha uzun süredir evsiz olma sürecini ifade etmektedir. Ravenhill (2008) evsizliğe ilişkin çatısız olanlar, konutsuzlar ve süreklilik göstermeyen biçimde barınaklarda yaşayanlar olarak üç tür sınıflandırma önermektedir. Çatısız olmak; geceleri sokakta uyumayı konutun bulunmaması, çadır, araba karavan gibi yerlerde kalınmasını vurgulamaktadır. Süreklilik göstermeyen biçimde barınaklarda kalmak ise; geçici konutlarda, otellerde, akraba veya arkadaş yanında kalanları ifade etmektedir. Sokakta yaşamak zorunda kalmak en önemli insan ihtiyaçlarından birini temsil eden barınma ihtiyacının giderilmesini engellemekte bunun yanı sıra hayatı tehdit eden birtakım sağllk ve güvenlik sorunları ile karşılaşılmasına neden olabilmektedir. Yoksulluk evsiz nüfusun önemli bir özelliği olmasına rağmen özellikle sosyal konut sıkıntısı yoksul olmayan bireyleri evsiz hale getirebilecek önemli bir risk faktörü olma özelliği taşımaktadır. İşsizlik, finansal kayıplar, ipotekler, ailede meydana gelen krizler, gelirle orantısız kira artışı evsizliği arttırmaktadır.

Evsizlik sorunu yaşayan nüfus grubunun önemli bir bölümünü kadınlar oluşturmakta ve evsizliğin yeni yüzünü karakterize etmektedir (Rossi, 1991). Evsizlik sorunu kadınların yaşamlarını sürdürebilmeleri açısından birçok risk ile karşı karşıya kalmalarına neden olmaktadır. Evsiz kadınlar barınaklarda, parklarda, köprü altlarında, kamuya açık alanlarda, başkalarının evlerinde yaşamak zorunda olan kadınlardır (Berzoff, 2013). Kadın evsizliği sosyal ve ekonomik adaletsizlik, cinsiyetçilik, ruh sağlı̆̆ sorunları ya da engelliliğin marjinalleştirilmesi gibi karmaşık faktörlerin etkileşiminden dolayı ortaya çıkmaktadır (Baxter,1991). Kadınlar ev içi şiddet, ekonomik zorluklar, ruhsal sağlık sorunları, aile desteğinin kaybı, boşanma, uyuşturucu/alkol kullanımı, cezaevi geçmişi (Zlotnick ve Zerger, 2009), ırkçılık ve ayrımcılık, ucuz konuta erişimde yaşanan güçlükler (Krupnick vd., 2008; Magee ve Huriaux, 2008) gibi nedenlerle evsiz kalabilmektedirler. Alan yazında yer alan çeşitli çalışmalarda çocukluk döneminde ihmal ve istismar yaşantılarının kadınların yetişkinlik dönemlerinde evsizlik sürecine geçmelerine neden olabileceği belirtilmektedir. Söz konusu çalışmalardan bazıları incelendiğinde; Belcher vd., (2001) yaptıkları çalışmada kamu tarafından finanse edilen 28 günlük madde bağımlılığı tedavi programına katılan 18 yaş altı çocuğu olan evsiz kadınlara ilişkin vaka kayıtları karşılaştırmalı olarak analiz edilmiş ve çalışma sonucunda kadın evsizliğinin nedenleri arasında çocukluk çağı ihmal ve istismar yaşantısı, aile içi şiddet, ekonomik istikrarsızlık, madde kötüye kullanımı ve sosyal izolasyon olduğu saptanmıştır. Kennedy vd., (2015) yaptıkları çalışmada ise 206 evsiz genç annenin çocukluk döneminde fiziksel ve cinsel istismar mağduru oldukları, yakın partner/eş şiddetine tanıklıklarının bulunduğu saptanmıştır. Alan yazında kadın evsizliğinin ani bir olay ya da kriz neticesinde değil aşamalı şekilde oluştuğu belirtilmektedir (Baxter ve Hopper, 1981; Coston, 1989).

Evsizlik sorunundan etkilenen kadınların bakmak zorunda oldukları çocukları olabilir ya da çocuksuz olabilirler (Smith ve North, 1994). Çocuğu olmayan evsiz kadınların genellikle yaşlı ve bekar oldukları, sıklıkla ruh sağlığı hizmetlerine gereksinimlerinin bulunduğu, alkol ve madde 
kullanım öyküsüne sıklıkla rastlanıldığı alan yazında belirtilmektedir (Johnson ve Cnaan, 1995). Evsizlik sorunu yaşayan kadınların aile ve arkadaşları ile etkileşimlerini sürdürme olasılıkları daha azdır, bu durum sosyal destek ağlarını azaltarak, evsizliğin kronik hale gelmesine neden olabilir. Yaşamlarını sokakta sürdürmek zorunda kaldıkları için birçok sağlık ve güvenlik sorunu ile karşı karşıya kalmaktadırlar. Muñoz vd., (2005) yaptıkları çalışmada evsiz olan kadınların \%33.3' ünde grip veya soğuk algınlığı semptomları, \% 30.6' sında iskelet sistemi sorunları, \%27.8' inde ise solunum problemlerinin bulunduğu saptanmıştır. En sık bildirilen kronik hastalıklardan bazıları ise astım, anemi, kronik bronşit, hipertansiyon ve ülserlerdir (Weinreb, 1998). Alan yazında yer alan birçok çalışmada evsiz kadınlarda başta depresyon olmak üzere, travma sonrası stres bozukluğu, alkol ve madde bağımlılığı (Bassuk vd., 1998; Weinreb vd., 2006) gibi ruh sağlı̆̆ sorunlarının yüksek oranda görülebileceği belirtilmektedir (Chambers vd., 2013). Waldbrook (2013) tarafından yapılan evsiz ve yaşlı kadınların sağlık, yaşlanma ve barınmaya ilişkin deneyimlerine odaklanan çalışmada; kadınların alkol ve madde bağımlılığı ile başa çıkabilmek ve gelir elde edebilmek için mücadele ettikleri belirlenmekle birlikte kadınların travma sonrası stres bozukluğu semptomlarını gösteren ifadeler kullandıkları belirlenmiştir. Araştırma sonucunda evsizliğin yarattığı travmanın kadınların düzenli şekilde konutta yaşamaya başlamalarından sonra bile birkaç yıl daha devam ettiği saptanmıştır. Schmidt vd., (2015)'nin 61 evsiz kadın ile Whitehorse, Yukon'da gerçekleştirdikleri 2 yıl süren araştırma projesinden elde ettikleri sonuçlara göre ise; kadınların yoksulluk, sosyal dışlanma, barınma ve bakım hizmetlerine ulaşamama gibi ağır sorunlarla karşı karşıya kaldıkları belirlenmiştir.

Evsizlik sorunu ile karşı karşıya kalan kadınlarla ilgili olarak yapılan çeşitli mortalite çalışmalarında bu kadınlarda HIV nedeniyle ölüm riskinin yüksek olduğu ifade edilmektedir (Caton vd., 2012). Evsizlik sürecindeki kadınlar hem cinsel yolla bulaşan hastalıklar açısından hem de HPV virüsü ile bağlantılı hastalıklarla ilgili olarak risk altındadırlar (Asgary vd., 2016). Evsizlik sağlık sorunlarının yanı sıra şiddete uğrama olasılığını da arttırmaktadır. Kişisel güvenlik eksikliği nedeniyle evsizlik sorunu yaşayan kadınlar bu tür bir sorun ile karşı karşıya kalmamış kadınlara göre fiziksel, cinsel ve psikolojik şiddete daha fazla maruz kalabilmektedirler (Zlotnick ve Zerger, 2009; Murray, 2011). Özellikle evsizlik kadınların cinsel şiddete maruz kalma riskini arttırabilmektedir (Goodman vd., 2006; Heslin vd., 2007; Lenon, 2000; Tyler vd., 2001). Kadınlar şiddetin yanı sıra dışlanma, toplumsal cinsiyet ve sosyal haklar bakımından eşitsizlik ile mücadele etmek zorunda kaldıkları için evsizlik sorunuyla daha da savunmasız hale gelmektedirler (Rosa, 2015). Bunların yanı sıra evsizlik istihdamdan dışlanmayı da beraberinde getirebilir.

Evsiz kadınların ve çocukların sağlık, eğitim, konut gereksinimlerinin giderilmesi, kadınların evsiz kalmalarına neden olabilecek toplumsal cinsiyet eşitsizliği, aile içi şiddet ve yoksulluğun önlenmesine yönelik politikaların oluşturularak temelde kadınların güçlendirilmesi uzun zamandır sosyal hizmet uygulamalarının merkezinde yer almaktadır. Sosyal hizmet savunmasız nüfus grupları için sosyal adaleti teşvik etmeye çalışmaktadır (NASW, 2015). Evsizlik sorunu yaşayan nüfus gruplarının sorunlarını ele alarak, onları güçlendirmeyi, evsizliğin yapısal bir sorun olduğu noktasından hareket ederek bu sorun ile mücadele edenlerin haklarının savunuculuğunun yapılması sosyal hizmet uygulamalarında önemli bir yer tutmaktadır. Söz konusu savunuculuk faaliyetleri evsizlerin krimanilize olmasının önüne geçilmesi, ucuz sosyal konutlara, hizmetlere, kaynaklara ve fırsatlara ulaşmalarını içermektedir. Ayrıca evsizlik sorun alanına yönelik sosyal hizmet uygulamaları evsiz bireylere yönelik baskıcı ve ayrımcı uygulamaların engellenmesine odaklanmaktadır. Fellin ve Brown (1989) evsiz bireylerle sosyal hizmet uygulamalarının vaka savunuculuğu, grup çalışmaları ve görev merkezli yaklaşım etrafında şekillenmesi gerektiğini belirtmektedirler. Evsizlerin yaşayabilecekleri çeşitli sorunların (yetersiz kaynaklar, rol performansı ve sosyal ilişkilerde yaşanan sorunlarla, kişiler 
arası çatışma) çözümlenmesine yönelik sosyal hizmet uygulamalarında görev merkezli yaklaşım aktif biçimde kullanılabilir. Kadın evsizliğine yönelik olarak gerçekleştirilen sosyal hizmet uygulamalarında feminist yaklaşım ve baskı karşıtı uygulamalar gerekli olan yaklaşımlardır. Feminist yaklaşım ve baskı karşıtı uygulama modeli kadın evsizliğinin ataerkil kültürel yapı ile olan bağlantısını ve güç ilişkilerindeki dengesizliğin altını çizerek kadınların hem mikro bağlamda hem de makro bağlamda güçlenmelerine olanak tanıyan fırsatları teşvik etmektedir.

$\mathrm{Bu}$ bağlamda kadın evsizliğinin görünür olmasının sağlanması, evsizlik sorunu yaşayan kadınların sorunlarının ve gereksinimlerinin belirlenmesi ve çözüm önerilerinin oluşturulması açısından bu çalışma önemli görülmektedir. Bunun yanı sıra uluslararası alan yazında kadın evsizliğine ilişkin çalışmalar bulunmasına karşın: Türkiye'de evsizlik çalışmalarında özellikle kadınları odak alan araştırmaların sınırlı düzeyde olduğu belirlenmiştir. Bu bağlamda araştırmanın alan yazına önemli katkılar sunabileceği düşünülmektedir. Bu araştırmada evsiz kadınların yaşadıkları sorunların betimlenmesi ve sosyal hizmet odağında çözüm önerilerinin geliştirilmesi amaçlanmıştır. $\mathrm{Bu}$ amaç doğrultusunda araştırmada evsizlik sorunu yaşayan kadınların sosyo-demografik ve biyopsikososyal sağlık durumlarına ilişkin özelliklerinin belirlenmesi ile evsizlik sürecine ilişkin deneyim ve düşüncelerinin betimlenmesi hedeflenmiştir. Araştırmada aşağıdaki şu sorulara cevap aranmıştır.

1.Kadınların evsiz kalmalarına neden olan faktörler nelerdir?

2. Evsizlik sürecinde kadınların karşılaştıkları riskler nelerdir?

3. Evsizlik sorun alanına yönelik olarak katılımcıların çözüm önerileri nelerdir?

\section{YÖNTEM}

Evsiz kadınların yaşadıkları sorunların betimlenmesinin amaçlandığı bu araştırma nitel araştırma yöntemlerinden durum çalışması olacak şekilde tasarlanmıştır. Durum çalışması gerçek yaşamda sınırlandırılmış bir durum ya da durumlar hakkında detaylı ve derinlemesine bilgiler elde edilerek bir durumun betimlenmesi ya da durum temalarının oluşturulduğu nitel bir yaklaşımdır (Creswell, 2016: 97). Durum çalışmasında araştırmacılar bir konu ya da soruna odaklanır sonrasında bu sorunu örneklemek için sınırlı bir durum seçilmektedir (Creswell, 2016: 99).

\section{Çalışma Grubu}

$\mathrm{Bu}$ araştırmanın çalışma grubunu İstanbul İlinde Beyoğlu ve Esenyurt ilçelerinde bulunan ve evsiz kadınlara barınma hizmeti sunan Şevkat-Der'e ait barınma evlerinde kalan; Taksim'de sokakta yaşayan ve çeşitli sivil toplum örgütlerinin yemek dağıtım hizmetinden yararlanan araştırmaya katılmaya gönüllü 22 kadın katılımcı oluşturmaktadır. Çalışma grubunda yer alan kadınların sosyo-demografik özellikleri ile biyopsikososyal sağlık durumlarına ilişkin bulgular Tablo 1 de gösterilmiştir. 
Tablo 1. Evsiz Kadınların Sosyo-Demografik Özellikleri ve Sağlık Durumları

\begin{tabular}{|c|c|c|c|}
\hline Yaş & $\mathbf{N}$ & Sosyal Güvence & $\mathbf{N}$ \\
\hline $18-25$ yaş arası & 2 & Sosyal Güvenceden Yoksun & 8 \\
\hline $26-35$ yaş arası & 7 & SSK & 9 \\
\hline $36-45$ yaş arası & 8 & Bağ-Kur & 1 \\
\hline $46-55$ yaş arası & 2 & Genel Sağlık Sigortası & 4 \\
\hline $56-65$ yaş arası & 2 & Gelir Durumu & \\
\hline 66 yaş & 1 & Emekli Maaşı & 4 \\
\hline Medeni Durum & & Yetim Aylığ & 6 \\
\hline Evli & 2 & Gelir Desteği Bulunmayan & 12 \\
\hline Bekar & 12 & Katılımcıların Çocuk Sayısı & \\
\hline Boşanmış & 4 & Çocuğu olmayanlar & 11 \\
\hline Eş vefatı & 4 & 1 Çocuk & 6 \\
\hline Eğitim Durumu & & 2 Çocuk & 4 \\
\hline Okur-yazar & 2 & 3 Çocuk & 1 \\
\hline İlkokul & 5 & $\begin{array}{l}\text { Evsizlik sürecinden önceki } \\
\text { istihdam durumları }\end{array}$ & \\
\hline Ortaokul & 4 & Çalışıyor & 7 \\
\hline Lise & 9 & Çalışmıyor & 15 \\
\hline Üniversite & 2 & $\begin{array}{l}\text { Evsizlik sürecinde çalışma } \\
\text { durumu }\end{array}$ & \\
\hline $\begin{array}{l}\text { Evsizlik sürecinde sosyal } \\
\text { yardımlardan yararlanma durumu }\end{array}$ & & Çalışıyor & 5 \\
\hline Yararlaniyor & 2 & Çalışmıyor & 17 \\
\hline Yararlanmiyor & 20 & Göç Öyküsü & \\
\hline $\begin{array}{l}\text { Yatılı Sosyal Hizmet Kuruluşlarından } \\
\text { Yararlanma Durumları }\end{array}$ & & Göç öyküsü var/Başka Ülkeden & 5 \\
\hline Evet & 3 & Başka şehirden & 6 \\
\hline Hayır & 19 & Göç Öyküsü Yok & 11 \\
\hline $\begin{array}{l}\text { Kadın Katılımcıların Sağlık } \\
\text { Durumlarına İlişkin Özellikleri } \\
\text { (Ruhsal Sağlık Durumları) }\end{array}$ & & Geçmişe ait cezaevi öyküsü & \\
\hline Ruhsal Sağlık Problemi Olmayanlar & 20 & Var & 2 \\
\hline Psikiyatrik Tanısı Olanlar (Depresyon) & 2 & Yok & 20 \\
\hline Sigara Kullanma Alışkanlığı & 18 & & \\
\hline Alkol Alma Alışkanlığ & 4 & & \\
\hline Fiziksel Sağlık Durumları & & & \\
\hline $\begin{array}{l}\text { Kronikleşmemiş Sağlık Problemi } \\
\text { Olanlar }\end{array}$ & 3 & & \\
\hline $\begin{array}{l}\text { Kronik Sağlık Problemi (Tansiyon, } \\
\text { Diyabet, Kadın Doğum Hastalıkları) }\end{array}$ & 15 & & \\
\hline Sağlık Problemi Bulunmuyor & 4 & & \\
\hline
\end{tabular}

Araştırmaya katılan ve evsizlik sorunu yaşayan kadınlar 18 ile 66 yaşları arasındadır. Katılımcılar arasında en çok bekar evsiz kadınların olduğu görülürken, boşanmış ve eşi vefat etmiş kadınların sayısı ise eşittir. Evli ve evsiz olan kadın katılımcılar ise sığınmacı statüsüne geçiş işlemleri devam eden ve eşleri Avrupa ülkelerinde yaşamakta olan kadınlardır. Katılımcıların eğitim durumları incelendiğinde evsizliğin en çok lise mezunu olan katılımcılarda olduğu görülmektedir. İkinci 
sırada ilkokul mezunları üçüncü sırada ise ortaokul mezunları, en az ise üniversite ve okuryazar olan katılımcılardır. Katılımcıların sosyal güvenlik sisteminden yararlanma durumları incelendiğinde en çok SSK'dan yararlandıkları görülmekte iken en az sayı ise Bağ-Kur'lu olan kadınlardır. Sosyal güvenceden yoksun olanların sayısı 8 iken, Genel Sağlık Sigortasından yararlananların ise 4 kişi olduğu belirlenmiştir. Evsiz kadınlar arasında gelir desteği bulunmayanların sayısının 12 olduğu görülmektedir. Araştırmanın çalışma grubunda yer alan evsiz kadınların 11'nin hiç çocuğu yokken, 11'inin ise çocuğu bulunmaktadır. Çalışma grubunda yer alan katılımcıların 7'sinin evsizlik sürecinden önce çalıştığ $1,15^{\prime}$ inin ise çalışmadığı; evsizlik sürecinde ise $17^{\prime}$ sinin çalışmadığ $5^{\prime}$ inin ise çalıştığı saptanmıştır. Evsiz kadınların 11'inin göç öyküsü bulunmazken 5' inin başka ülkeden, 6'sının ise iç göç öyküsü bulunmaktadır. Çalışma grubunda yer alan katılımcılar arasında geçmiş yaşantılarında ceza adalet sistemi ile temas etmiş kadın sayısının 2 olduğu belirlenmiştir. Kadın katılımcıların sağlık durumlarına ilişkin özellikleri incelendiğinde; katılımcılar arasında ruhsal sağlık probleminin olmadığını belirten katılımcı sayısı 20 iken, ruh sağlığı problemine ilişkin tanısı olanların sayısı 2' dir. Katılımcılar arasında 18 kişide sigara içme alışkanlığı varken 4 kişi de sigara kullanımının olmadığı, 4 kadın katılımcı da ise yoğun olmamakla birlikte alkol tüketimi bulunmaktadır. Katılımcılar arasında 3 kadın boğaz ağrısı, baş ağrısı ve öksürme gibi şikayetlerinin olduğu, 15 kadın ise tansiyon, diyabet ve jinekolojik hastalıklara ilişkin tanılarının bulunduğunu ifade etmiştir.

\section{Veri Toplama Araçları}

Araştırmada veri toplama aracı olarak kadınların evsizlik sürecinde yaşayabilecekleri sorunların görünürlüğünün sağlanması amacıyla araştırmacılar tarafından geliştirilmiş yarı yapılandırılmış görüşme formu kullanılmıştır. Görüşme formunda yer alan ilk 10 soru katılımcıların sosyodemografik özellikleri ile sağllk durumlarının belirlenebilmesi amacıyla oluşturulmuştur. Sorular belirlenmeden önce alan yazında yer alan kaynaklar incelenmiş sonrasında sorular oluşturulmuştur. Görüşme formunda yer alan 17 soru ise açık uçlu olacak şekilde katılımcıların evsizliğe ilişkin düşüncelerinin ve görüşlerinin belirlenmesi amacıyla tasarlanmıştır.

\section{Veri Toplama Süreci}

Araştırmaya başlamadan önce Gümüşhane Üniversitesi Bilimsel Araştırma ve Yayın Etiği Kurulundan 2019/11 sayı ile Etik Kurul onayı alınmıştır. Katılımcılara görüşmelere başlamadan önce bilgilendirilmiş onam formu sunulmuştur. Araştırma 27.01.2020-07.02.2020 tarihleri arasında İstanbul İlinin Beyoğlu, Esenyurt ilçelerinde ve Taksim'de gerçekleştirilmiştir. Araştırmacılar çalışmanın zaman seçimine özen göstermişlerdir. Bunun nedeni olarak evsizlerin özellikle kış mevsiminde belirli barınma merkezlerinde kalma yönünde tercihte bulunmaları ile açılanabilir. Araştırma kapsamında veriler katılımcılar ile yapılan yüz yüze derinlemesine görüşmeler yoluyla toplanmıştır. Katılımcılar ile gerçekleştirilen görüşmeler $45 \mathrm{dk}$. sürmüştür. Katılımcılar ile yapılan derinlemesine görüşmelerde ses kaydı alınmamış bunun yerine araştırmacılar tarafından görüşme detayları, ifadeler yazılı olarak alınmıştır.

\section{Verilerin Analizi}

Katılımclar ile gerçekleştirilen derinlemesine görüşmelerin fenemonolojik analiz yöntemi ile yapılmıştır. Fenemonolojik veri analizi dar kapsamlı analizden başlayan ve daha geniş birimlere doğru ilerleyen ve ardından bireylerin "neyi" "nasıl" deneyimlediklerinin detaylı betimlenmesine doğru sistemli bir süreci devam eder (Moustakas, 1994). Fenomenolojik analizde bir katılımcının ifadeleri ayrıntılı incelendikten sonra, diğer katılımcının ifadelerinin ayrıntılı incelenmesine geçilmektedir (Smith, 2004). Fenemonolojik veri analizi verilerin hazırlanması, elde edilen 
verilerin fenemonolojik olarak azaltılması, yaratıcı varyasyon ve deneyimin özünün ortaya çıkarılmasından oluşmaktadır (Kleiman, 2004:11-15; Tekindal ve Uğuz Arsu, 2020: 170). Bu bağlamda ilk önce katılımcılar ile yapılan görüşmeleri içeren notlar araştırmacılar tarafından harf kodu verilerek bilgisayar ortamında Microsoft Word dosyasına aktarılarak 66 sayfalık metin elde edilmiştir. Veriler birbirlerine benzeyen belirli tema ve kavramlar çerçevesinde bir araya getirilerek yorumlanmıştır. Metin içerisinde geçen katılımcıların ifadeleri teker teker araştırmacılar tarafından tekrar döne döne okunarak, incelenerek, müzakere edilerek bütüncül biçimde analiz edilmiş ve katılımcıların ağırlıklı olarak belirttikleri durumlar başlıklar altında ele alınmıştır. Veri analizinden finansal kayıplar, ev içi şiddet, aile içi ilişkilerde yaşanan sorunlar, işsizlik, göç, kira maliyeti nedeniyle evsiz olma durumları ile evsizlik sürecinde karşılaşılabilecek risklere (suç mağduru olmak, şiddet, bulaşıcı hastalık, kronik hastalık, açlık ve soğuk) ilişkin durumlar 3 ayrı başlık altında detaylandırılmıştır. Sonrasında katılımcılardan elde edilen veriler alan yazında yer alan çalışmalar ile ilişkilendirilmiştir.

\section{BULGULAR ve YORUM}

Bu bölümde katılımcıların evsizlik sürecine geçme nedenlerine ilişkin düşünceleri ile evsizlik sürecinin kadınlar için barındırdığı risklere ilişkin düşüncelerine yer verilerek alan yazınla birlikte değerlendirilmiştir. Çalışmanın amaçları doğrultusunda katılımcılardan elde edilen bulguların dağılımı Tablo 2' de gösterilmiştir.

Tablo 2. Kadın Katılımcıların Evsizlik Sürecine İlişkin Deneyimlerinin ve Düşüncelerinin Dağılımı

\begin{tabular}{lc}
\hline Katılımcıların Evsizlik Sürecine Geçme Nedenleri & N \\
\hline Finansal Kayıplar & 2 \\
Ev içi Şiddet & 1 \\
Aile içi İlişkilerde Yaşanan Sorunlar & 6 \\
İşsizlik & 3 \\
Göç Sonrası Gelinen Ülkede Sosyal Destek Sisteminden Yoksunluk & 5 \\
Ev Kira Maliyetinin Yüksek Olması & 5 \\
\hline Evsizlik Nedeniyle Kadınların Karşılaşabilecekleri Risklere İlişkin Düşünceler & \\
\hline Sokakta Suç Mağduru Olmak & 4 \\
Şiddete Uğramak & 5 \\
Bulaşıcı Hastalıklar & 3 \\
Kronik Hastalığın Oluşması & 3 \\
Açlık ve Soğuk & 7 \\
\hline
\end{tabular}

\section{Katılımcıların Evsiz Kalma Nedenleri}

Araştırma kapsamında ilk önce evsizlik sürecindeki kadın katılımcıların evsizlik sürecine geçmelerinde etkili olan faktörler ele alınmıştır. Söz konusu faktörler kadınların kendi deneyimlerinden yola çıkarak oluşturdukları kendi anlatıları etrafında toplanmaktadır. Bu bağlamda ilk önce finansal kayıplar nedeniyle evsiz olma durumuna; ikinci olarak ev içi şiddete, üçüncü olarak aile içi ilişkilerde yaşanan sorunlara, sonrasında işsizlik, göç ve son olarak kira maliyetine ilişkin görüşlerine yer verilmiştir.

Finansal kayıplar nedeniyle evsiz olma durumu çalışma grubunda yer alan 2 katılımcı tarafından ifade edilmiştir. Alan yazında finansal kayıplar nedeniyle bireylerin evsizlik sorunu ile 
karşılaşabilecekleri belirtilmektedir. Özellikle kırılgan ekonomik sistemlerde güvencesiz geçim kaynaklarına sahip olanlar mali kayıplarla sıklıkla karşılaşılmaktadır ve bu durum evsizliğe neden olabilmektedir (Wisner, 1998: 28). Ekonomik açıdan evsizliğe zemin hazırlayan bir diğer faktör ise ekonomik kaygılardır (MacKenzie vd., 2007). Temel gereksinimlerin karşılanmasında ve yeterli yaşam standardının sürdürebilmesinde ekonomik açıdan yetersizlik olarak tanımlanan finansal stresin (Yates, 2007) oluşumunda etkili olan unsurlar; finansal açıdan dengenin kaybedilmesine yol açan sağlıksız düşünme yolları, bireyin kontrolünde olmayan dışsal koşullar, para yönetiminde bilgi ve beceri eksikliği (Marston ve Shevellar, 2010) olarak siralanabilir. Finansal kayıplar aile içi ilişki örüntülerinde çatışmalara neden olarak bireylerin sosyal desteğinin azalmasına yol açabilmektedir. Finansal kayıplar nedeniyle evsiz olma durumunu çalışma grubunda yer alan $\mathrm{S}$ ve $\mathrm{M}$ şu şekilde belirtmektedir:

“...Eşimin işleri çok iyiydi, hiçbir maddi sorunum yoktu ancak sonrasında iflas etti ve ardından da kalp krizi geçirerek vefat etti. Bilseydim öncesinde tedbir alırdım"...(S.66)

"...Ailemin maddi durumu çok iyiydi ancak sonrasında birdenbire her şey gitti. Eş, dostta kalmadı, kimsenin yaninda kalınamıyor."... (M.36)

Finansal kayıplar nedeniyle evsiz olma durumunun dışında ev içi şiddet kadınların evsiz kalmalarına neden olabilmektedir. Alan yazında ev içi şiddetin kadınların evsizlik sorunu ile karşı karşıya kalmalarında itici bir güç olduğu (Jasinski vd., 2005; Marpsat, 2000) sıklıkla vurgulanmaktadır. Browne (1993) ataerkil kültürel kodlar ile beslenen aile içi şiddetin kadınların evsiz olmalarında önemli rol oynadığını vurgulamaktadır. Alan yazında ev içi şiddetin evsizlik sürecine geçişte önemli bir etken olabileceği sıklıkla vurgulanmasına rağmen çalışmada bir katılımcı ev içi şiddet nedeniyle evi terk ettiğini ve birlikte yaşayabileceği kimsenin bulunmadığını ifade etmiş̧tir. Eşi tarafından şiddete maruz kalan ve bu nedenle belirli bir dönem kadın sığınma evininde kaldıktan sonra evsizlik sorunu yaşamaya başlayan C söz konusu durumu şu şekilde ifade etmektedir:

"...Kocam ile kaçarak evlendik, kendi ailem benimle konuşmadı. Beni o denli daralttı ki arkadaşlarım ile görüşmemi dahi istemedi, evleneli daha 6 ay olmuştu, her gün dayak. İstanbul' da kimsem yoktu. Kaçtıktan sonra kimse sahip çıkmıyor, seni siliyorlar. Hiç birisi ile görüşmüyorum. Burada tanıdı̆̆ım birkaç insan var, bazen onların yanında kahıyorum ara sıra. Sı̆̆ınma evinde kaldım bir süre ancak kurallar çok katıydı şimdi günlük iş bulduğum yerlerde çalışıyorum kendi ihtiyaçlarım için, ama o da yetmiyor."... (C.24)

Araştırmadan elde edilen bulgulara göre aile içi ilişkilerde yaşanan sorunlar nedeniyle kadınlar evsiz kalabilmektedirler. Sinha (2013)'ya göre her yıl milyonlarca insan aile içi ilişkilerde yaşanan çatışmalar nedeniyle evsizlik sorunu ile karşılaşmaktadır. Evsizlerin aile ilişkilerinde üyeler arasında katmanlaşmış uzaklığa ve çatışmaya dayalı ilişki örüntüsüne rastlanabilmektedir. Çalışma grubunda yer alan kadınlar kişiler arası sorunları konut sorunu ile birlikte tanımlamışlardır. Çalışma grubunda yer alan 6 katılımcı söz konusu durumu şu şekilde ifade etmiştir;

“...Abim, eşi ve çocuklar annem ve benim yaşadığımız eve geçinemediklerini için geldiler, abimin maaşı yetmiyordu. Ev küçüktü; abim, eşi ve ben sürekli tartışıyorduk; bir de onların arasında da geçimsizlik var, seslerimiz artık sokaktan duyuluyordu ben de evden çıktım, evde huzursuzluk vardı."... (D.34)

“...Annem ve ben anlaşamıyorduk, biz çok kardeşiz, baba yok. Ne yapayım arkadaşımın da aynı sorunları vardı o da, bende evi terk ettim. Katlanilmiyordu."... (Y.28)

"...Eşim vefat etti, vefat etmeden önce de onun ailesi ile anlaşamazdik, vefat ettikten sonra eşimin ailesi bize bakamayacakların söylediler, yerimiz yok, güle güle dediler."... (L.42) 
“...Annem vefat etti, babam ise bir başka kadın ile birlikteydi, babaannemlere gittik kardeşlerimle o da vefat edince babamın kı kardeşleri babaannemin evini bizden aldılar, bizde evsiz, yersiz, yurtsuz kaldık, ne söyleyeyim."... (F.26)

"...Akraba, eş, dost evin yoksa sıkıntıdaysan kimse yardım etmez, çocuğun bile. Beni gelin istemedi eşim vefat ettikten sonra, evleri çok küçükmüş bu şekilde söylediler, huzur evine de gidemedim, aldım bavulumu evden çıktım, eş dostun yanında kaldım, yük oluyorsun bir süre sonra."... (N.54)

"...Benim kimsem yok yani var da yok, yuva ve yurtlarda geçti benim tüm hayatım, baba vefat etmiş annemde başkası ile evlenmiş beni ve kardeşimi vermişler yuvaya yıllar önce ailemin yanına döndüm ama onlarla yapamadım bir kere sığıntı oluyorsun, sanki senin annen değil gibi oluyor bir süre sonra, gelemedim."... (R.23)

Kadınların cinsiyet ayrımcılığı nedeniyle iş yaşamında yeterince yer bulamamaları da evsizlik sorunu karşısında kırılgan olmalarına neden olabilmektedir. İşgücü piyasasındaki cinsiyet ayrımcılığı, kadınları işsiz kılarak kadın evsizliğinin en önemli nedenlerinden birini oluşturmaktadır (Olufemi, 2000). İşsizlik, sosyal güvenceden ve düzenli gelirden yoksun kılarak barınma ihtiyacının karşılanmasını da engellemektedir (Tessler vd., 2001). İşsizlik nedeniyle evsiz olma durumu çalışma grubunda yer alan 3 katılımcı tarafından şu şekilde dile getirilmiştir. “...Tekstilde çalışıyordum, çıkarttılar. Kiramı karşılayamaz oldum. Bankalara borcumda var"... (B.45)

"...Çalışmak istedim ama iş bulamadım, iş vermiyorlar, bu durumda evde tutulamıyor."... (Z.39)

"...Daha az ücretlere çalışan yabancı uyruklu kadınları çalıştırıyorlar, iş aradım ancak bulamadım, ev de tutamadım."... (K.26)

Araştırmaya katılan kadınlardan 5'i Türkiye Cumhuriyeti vatandaşı değildir. Evsizlik sorunu göç öyküsü olan kadınlarda görünür olmaktadır. Göçmenler, sığınmacı ve mülteciler yoksulluk, yerel topluluktan dışlanma, konut kiralama ve konaklamadaki ayrımcı uygulamalar nedeniyle evsizlik açısından risk altındadırlar (Thomas, 1995; Abraham, 2000; Baker vd., 2003). Göç sonrası gelinen ülkede yakının (aile, arkadaş) ve sosyal destek sistemlerinin olmaması nedeniyle kadınlar evsizlik sorunu ile karşılaşabilmektedirler. Kadınlar gelinen ülkenin dilinin konuşulamaması nedeniyle çoğunlukla sosyal yönden izole bir yaşantı sürmektedirler (Sikich, 2008) ve evsizlere ilişkin sosyal hizmetlere ulaşımda sorun yaşayabilirler. Araştırmaya katılan kadınlardan 2'si Sudan, 1'i Mozambik, 2 kadın ise Ekvador kökenlidir. Araştırmacılar katılımcılar ile İngilizce konuşarak ve Mozambik'li kadın katılımcının tercüme desteği ile görüşmeleri yapmışlardır. Farklı ülkelerden olan 5 kadın evsizliğe ilişkin süreçleri şu şekilde dile getirmişlerdir:

“...9 ay önce Türkiye'ye Sudan'dan geldim, pasaportum yok, evliyim, 3 çocuğum var, çocuklarm süt, mama ve bez ihtiyaçları var, barınma yerini facebook aracılı̆̆ı ile öğrendim, burası da çocuklar için yetersiz çocuklar buradan hoşlanmıyorlar, eşim Avrupa'ya gidebildi, iş yok."... (Ş.28)

"...Bekarım kardeşim Ş ile birlikte geldik, pasapotumuz yok, kardeşim ve ben burayı facebookdan öğrendik, bu dernek dışında yardım almadık, başka yerden sosyal yardım almadık."... (E.32)

“...İstanbul'a işletme bölümü okumak için geldim. Gebelik durumum oldu ve yurttan çıkarıldım, çocuğum 3 yaşında, arkadaşlarımın evinde kaldım sonrasında ise buradayım, Sosyal Hizmetlerden yardım almadım, gönüllülerden yardım aldım. Kimi zaman aç kaldığım zamanlar oldu. Ailem ile görüşüyorum onlar Mozambik'te. Çocuğumun babası ile görüşmüyorum."... (U.27)

“...Bekarım, çocuğum yok, Ekvador'dan 9 yıl önce geldim, havalimanında yakalandım, 7 sene 5 ay ceza evinde kaldım, şu anda denetimli serbestlikten yararlanıyorum, ülkeme geri dönmek istiyorum, çalışmak istiyorum ülkeme geri dönebilmek için para biriktirmek istiyorum, cezaevinden sonra sokakta kaldım. Ailem Ekvador da ve görüşüyorum"... (Ö.41)

“...Bende bekarım, çocuğum yok, 7 yıl önce Ekvador'dan Türkiye'ye geldim, Ö gibi ben de ceza evinde kaldım, sokakta kaldım sonrasında facebook ile burayı buldum. Ekvador'a geri dönebilmek istiyorum, çalışıp para biriktirmek istiyorum, kardeşim, annem ve babam ile görüşüyorum."... (Ç.36) 
Kadın katılımcılardan 27 yaşındaki U gebelik süreci ile birlikte barınma imkanlarından yoksun kaldığını belirtmiştir. Üniversite öğrencisi olan kadınların gebelik durumlarının oluşması durumunda destek sistemlerinin aktifleştirilmesi ve barınma sorunlarının çözümlenebilmesi için sosyal politikalara, kurumlara ve sosyo-ekonomik destek mekanizmalarına ihtiyaç duyulmaktadır. Katılımcılar arasında göç öyküsü olan 2 kadın katılımcıda aynı zamanda suç öyküsünün de bulunuyor olması cezaevi sonrasında kadınların sosyal ve ekonomik destek sistemleri ile bağlantılarının kurulmasında yardım mekanizmalarının yetersiz kalabildiğini göstermektedir. Göç öyküsü olan 3 kadın katılımcının kalacak barınma yeri bulmada sosyal medya hesaplarından faydalanmaları sosyal medyanın bireylerin gerekli kaynaklara ulaşmalarında önemli bir etken olduğunu göstermektedir.

Konut kira maliyetinin yüksek olması nedeniyle de evsizlik sorunu oluşabilmektedir. Poremski vd. (2015) evsizliğin en önemli 2 nedeni olarak gelir eksikliği ve konut maliyetini belirtmektedirler. Kira maliyeti yoksulluk sorunu yaşayan dezavantajlı grupların giderlerinin büyük bir bölümünü oluşturmaktadır (Işıkhan, 2002: 41). Ev kiralarının yüksek, hane içine giren gelir miktarının az olması yoksulluk ile birlikte kadın evsizliği için risk faktörünü oluşturmaktadır (Shinn ve Khadduri, 2020). Yoksulluk kadınların bağımsız ev kurma kapasitelerini zayıflatarak evsizliğe karşı savunmasızlı̆̆ı arttırmaktadır. Kira maliyetlerinin yüksek olması nedeniyle evsiz olma durumu çalışma grubunda yer alan 5 kadın katılımcı tarafından yaşam öyküleri içinde doğrudan ifade edilmiştir. Söz konusu görüşlere bakıldığında; “...Ev kiralar çok yüksek, ben ailemden herkesi kaybettim, İstanbul da doğdum ve büyüdüm ancak bir evim olamadı, tek başına ev tutulamaz, bir işte çalışsak dahi İstanbul da 800-1000 TL'nin altında ev bulmak çok zor, elektrik, su, yol masrafı ve doğalgaz faturaları yüksek, 2-3 arkadaş bir araya gelip ev tutalım diyoruz, yalnız yaşayan, evli olmayan kadınlara kimse ev vermiyor. Çok ucuz bir konutta oturursan da o bölge çok güvenli olmuyor."... (A.38)

“...Ben çalışıyordum ve işimi kaybettim, üniversite mezunuyum, İstanbulluyum hem de kaç kuşak öncesinden, bankalara kredi ve kart borcum çok, arkadaşlarımın hepsi hayatlarına devam ediyorlar, iş bulup çalışmak istiyorum, ancak bulamıyorum, barınma merkezinde kaldı̆̆ımı söyleyince tüm iş görüşmelerim orada kalıyor. Kimse evsiz birini işe almak istemiyor, 2-3 arkadaş birlikte ev tutalım diyoruz ancak ev vermiyorlar, bulduğumuz yerlerde de ev kiraları çok yüksek, depozitosu var, 1500-2000 TL'nin altında kadınlar için rahat edebilecekleri bir yerde oturamazsınız. Bu barınma yerinde kaldığımız için apartmanda birileri ile karşılaşıyoruz ve insanların bakışları tuhaf, çünkü burada kaldığımızı biliyorlar. Evsiz olmak aynı zamanda sizi işsiz kılıyor."... (V.40)

“...Herkes hayatta tökezleyebilir, benim ve arkadaşların olduğu gibi, ucuz konut gerekli, bakın bizim hiç birimizin ruhsal sağllk sorunumuz yok, suç geçmişimiz yok ve İstanbulluyum, ev kiraları çok yüksek, işsiz kalındığında borç çok olduğunda nasıl ev tutalım, hiç kimse evsiz kalıpta sokakta, barınma merkezlerinde kalmak istemez. Ben çalışıyorum ve ev tutabilmek için para biriktirmeye çalışıyorum, ancak evim barkım ve kimsemin olmadığın biliyorlar ve işler de bu nedenle geçici olabiliyor. Ev kiralayabilmek için yeterli para da olamiyor bu nedenle"... (T.47)

"...Bende gündelik işlerde çalıstım bir süre, verilen ücretler çok düşük onunla bir oda bile kiralayamazsin."... (I.58)

"...Evladım bakın ben bu yaşımda matbaa da çalışıyorum, sabah saat yediden akşam saat 7'ye kadar ve ev kiraları çok yüksek olduğu için evsiz kaldım, damadımın ve kızımın yanına sığamıyorum, huzur evinde de kalmak istemiyorum. Bu tür durumlar için ucuz kiralanabilecek konutlar şart, bă̆-kur emekli aylığım var ancak bankaya kesiliyor"... (S.66)

Konut hakkının sosyal bir hak olarak tanınıp tanınmama sorunsalı ile sosyal konutlara ilişkin sosyal politikalar ve uygulamalar evsiz sayısının artmasına ya da azalmasında önemli bir belirleyicidir (Busch-Geertsema vd., 2010). Özellikle ucuz sosyal konutlara erişim sosyal riskler 
ile karşı karşıya kalan kadınları evsizlikten koruyabilmektedir. Bu bağlamda ucuz kira maliyeti olan konut uygulamalarının oluşturulmasına gereksinim duyulmaktadır.

\section{Evsizlik Nedeniyle Kadınların Yaşadıkları Riskler}

Kadınlar evsizlik sürecinde yaşamlarını tehdit eden birçok risk ile karşılaşmaktadırlar. Söz konusu riskler şiddete ve istismara maruziyet (Wenzel vd., 2000; Zlotnick ve Zerger, 2009:29), yaralanma ya da ölüm, suç mağduru olma, cinsel yolla bulaşan hastalıklar başta olmak üzere çeşitli kronik ya da bulaşıcı hastalıkların görülmesi şeklindedir. Bu çalışmada kronik böbrek hastalığı, kadın doğum hastalıkları, ülser ve diyabet katılımcılar tarafından bildirilmiştir. Ayrıca evsizlik ile iç içe geçmiş yoksulluk sarmalında kadınlar temel besin maddelerine ulaşımda ve mevsim şartlarına göre giyecek temininde ve isınmada sorunlar yaşamaktadırlar. Evsizlik başlı başına kadınların yaşam hakkını ve biyopsikososyal sağlığını tehdit eden sorunlara neden olmaktadır.

Çalışma grubunda yer alan kadınların evsiz olma durumunda sokakta karşılaşabilecek risklere ilişkin düşünceleri incelendiğinde 4 katılımcı kadınların sokakta suç mağduru olabileceklerini belirtmiştir. Söz konusu ifadeler incelendiğinde;

“...Kadınlar sokakta hırsızliğa maruz kalabilirler, yaralanabilir ya da öldürülebilirler."... (S.66)

“...Sokakta bir gözün açık uyumalısın, nereden nasıl bir zarar geleceğini bilemezsin, canından olabilirsin. Sokakta iken en güvenilir yer hastanelerdir, orada güvenlik görevlileri ve polisler vardır. Rahatsız eden olmaz. "... (R.23)

“...Bir şey yapsam kimi kimsesi yok diye düşünürler, o nedenle sokakta çok dikkatli olmak gerekir, senden çalmaya çalışabilirler."... (N.54)

“...İnsanların yoğun olduğu yerlerde bulunmalısın yardım isteyebileceğin birileri olur, yaralanabilirsin, öldürülebilirsin."... (M.36)

Alan yazında yer alan çeşitli çalışmalar evsizlerin genel nüfus içinde suç mağduru olma riskinin yüksek olduğunu göstermektedir (Lam ve Rosenheck, 1998). Evsizlerin kalıcı konut gibi koruma kaynakları olmadığı için suç mağduru olma riskleri artmaktadır (Lee ve Price-Spratlen, 2004). Evsizlik sürecinde özellikle kadınların erkek evsizlerden daha fazla suç mağduru olabilecekleri (hırsızlık, gasp), kadınların öldürülme, vurulma ya da yaralanma riskinin erkek evsizlere göre daha yüksek olduğu (Jasinski vd., 2005: 4) alan yazında belirtilmektedir. Bu bağlamda katılımcıların dile getirdiği görüşler ile alan yazında yer alan çalışmalar benzerlik göstermektedir.

Çalışma grubunda yer alan 5 katılımcı kadınların sokakta şiddete uğrayabileceklerini belirtmiştir. Söz konusu ifadeler incelendiğinde;

“...Sokakta kadınları koruyabilecek hiçbir şey yok gerçi evlerde de yok, en iyi ihtimalle kötü, çirkin sözler işitebilirsiniz sokakta, hoş olmayan bakışlarla karşılaşabilirsiniz. Bir kere horlandığınızı hissettirirler size."... (T.47)

“...Kadınların kimsesi yoksa, yalnızlarsa ve başlarının üstünde bir çatıları yoksa sokakta hırpalanabilirler, dövülebilirler kısaca her şey olabilir."... (L.42)

"...Şiddete maruz kalırlar. Belki öncesinde şiddet olmayabilir ancak sokakta şiddet ile tanışırlar. Aklınıza gelebilecek her şey olabilir sokakta, cinsel taciz mesela"... (F.26)

"...Kendi yakınına yapmayacağı her türlü kötü davranışı sokaktaki kadına yapabilirler neden çünkü korunmasızdır, insan olduğu kolaylikla unutulur, insanların değer verdikleri sende yoktur çünkü."... (D.34) 
“...Burası olmasaydı başıma sokakta çok kötü durumlar gelebilirdi, bir kere gece uyuyamazsın sokakta her zaman tetikte olmalısın, dövebilirler aklına gelebilecek her türlü olumsuz durum ile karşılaşırsın." ...(Ş.28)

Alan yazında yer alan çeşitli çalışmalar kadınların sokakta fiziksel, cinsel ve psikolojik şiddete maruz kalabildiklerini göstermektedir. Evsiz olan erkekler sokakta gündelik yaşam pratiklerinde şiddet içeren davranışlar ile karşılaşsalar da özellikle kadınlar cinsel şiddet açısından da risk altındadırlar (Heslin vd., 2007; Wenzel, vd., 2000). Hatty (1996) tarafından yapılan çalışmada evsizlik sorunu olan kadınların şiddeti evsizliğin ayrılmaz bir parçası olarak gördükleri belirlenmiştir. Söz konusu bulguya göre kadınların evsizlik sürecinde şiddeti içselleştirdikleri söylenebilir. $\mathrm{Bu}$ araştırmada kadınlar evsizlik sürecinde sokakta karşılaşabilecek riskleri betimlerken şiddet görünümlerini de tasvir etmişler ve evsizlik süreci ile ilişkilendirmişlerdir. Bu bağlamda araştırmanın bu bulgusu alan yazında yer alan çeşitli çalışmalar ile örtüşmektedir.

Evsiz kadınlar birçok hastalık bakımından risk altındadırlar. Çalışma grubunda yer alan 6 kadın sokakta bulaşıcı ve kronik hastalıklara maruz kalınabileceğini belirtmiştir. Söz konusu ifadeler incelendiğinde;

“...Bir başkasında hastalık olur ve size bulaşabilir, sokaktaki insanlar kendilerine bakamazlar, banyo yapamazlar, başkalarının eski kıyafetlerinden de hastalık bulaşabilir çok zor, bir arkadaşta uyuz vardı mesela"... (Z.39)

"...Bir arkadaşım bir adamla birlikte olmuştu ve hastalık kapmıştı."... (Ö.41)

"...Nezle, gribin yanında bir de verem olabilirsin, çünkü başını sokmak için mekruh binalarda kalmak zorunda kalırsin temiz olmayan yerler hastalik yapar."... (U.27)

"...Ben evde iken să̆ h̆ğıma dikkat ediyordum, yeterince su içmediğgim için böbreklerimden rahatsızlandım. Böbrek hastalı̆̆ım var şimdi, yeterince su içmemişim."... (E.32)

"...Sokakta kaldığım süreçte bronşit oldum bir de şeker hastalığı ile depresyonum varmış."... (V.40)

“...Bel ağrılarım var ve midem kötü ülser varmış, doktora da gidemedim, kadın hastahı̆̆ım ve depresyon var bir de."... (B.45)

Evsizlik süreci kadınların fiziksel sağlıklarını etkileyerek öncesinde kendilerinde olmayan hastalıkların oluşumunu arttırmakta ya da olumsuz yaşam koşulları nedeniyle önceden var olan hastalıkların şiddetinde artışa sebep olabilmektedir. Araştırmanın çalışma grubunda yer alan kadınlar evsizliğin sağlık açısından risk taşıdığını dile getirmişler ve farklı hastalıkların bu süreç ile bağlantılı olarak ortaya çıkabileceğini belirtmişlerdir. Araştırma grubunda yer alan katılımcılar arasında ruhsal sağlık problemi sadece 2 katılımcı tarafından depresyon olarak bildirilmiştir. Evsizlik dışlanmayı, yoksulluk ve yoksunluk yaşantısını beraberinde getirerek bireylerde duygusal sıkıntıya ve depresyona katkıda bulunabilir. Alan yazında yer alan çeşitli çalışmalarda evsizliğin ruhsal sağlık problemlerine yola açabileceği ve ruhsal sağlık problemlerinin de evsizliğe neden olabileceği (Greifenhagen ve Fichter, 1997: 162) ifade edilmektedir. Bu çalışmada ruhsal sağlık problemlerine ilişkin ifadeler 2 katılımcı tarafından dile getirilmiştir.

Evsizlik durumunda kadınlar yeterli ve güvenli besin maddelerine ve hava koşullarına göre yeterli giyeceğe ve ısınma imkanlarına ulaşımda zorluk yaşamaktadırlar. Çalışma grubunda yer alan 7 kadın sokakta kalınan süreçte kadınların besin ve soğuktan korunma gereksinimlerini karşılayamaz duruma gelebileceklerini ve kış aylarında soğuk nedeniyle zorluk yaşayabileceklerini belirtmiştir. Söz konusu ifadeler incelendiğinde;

“...Açlık çok zor, insanlardan bir şey istemek de, Taksim de yemek dağıttliyor hepimiz gönüllü olarak taşınmasına, yapımına yardım ediyoruz."... (C.24)

“...Kış aylarında soğuk çok büyük sıkıntı."... (K.26) 
“...Hastanelere gidiyoruz sıcak oluyor içerisi, kimsenin kışın sokakta kalmasını istemem."... (Ç.36)

"...Sıcak yemek dağıtımı oluyor burada ama olmayan yerlerde var, evsiz barksız kalmış olanlara düzenli olarak her yerde yemek verilmeli, aşevleri olmall, kimse aç bırakılmamall, insanlardan yemek için para istemek zor, kadinsan daha da zor."... (A.38)

"...Kış aylarında soğuk ve aç kalmak ikisi her insan için büyük sorun evsizsen daha büyük sorun kadınsan daha da büyük." ...(I. 58)

“...En büyük imtihan kimsesiz, evsiz barksız kalmak ama en kötüsü de soğukta ayazda başını sokacak bir çatının olmaması ve aç kalmak."... (S.66)

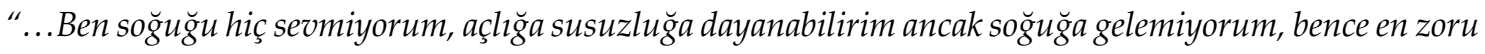
karda kışta soğukta dışarıda kalmak."... (Y.28)

Alan yazında da evsizlerin yiyecek, barınak, kıyafet ve yıkanacak yer bulmakta güçlük yaşayabilecekleri belirtilmektedir (White ve Newman, 2014: 81). Sağllklı beslenememe ve insan yaşamı için gerekli olan besin maddelerine ulaşılamaması evsizler için bir yandan hastalık riskini beraberinde getirirken diğer taraftan ise ölüm riskini arttırabilmektedir. Ayrıca çalışma grubunda yer alan katılımcıların belirttiği gibi soğuğun yoğun biçimde hissedildiği hava koşullarının evsizlerin yaşam koşullarını olumsuz biçimde etkileyebileceği ve ölüm riskini arttırabileceği (Romaszko vd., 2017) alan yazında da belirtilmektedir. Açlık ve soğuk kadın ve erkek evsizleri ortak biçimde etkilemektedir.

\section{Evsizlik Sorun Alanına Yönelik Olarak Katılımcıların Çözüm Önerileri}

Araştırmada yer alan katılımcılar ucuz konuta erişimde yaşadıkları sorunları dile getirip, çözüm önerisi olarak risk altındaki kadınlar için ucuz sosyal konutların gerekli olduğunu vurgulamışlardır. Söz konusu ifadelerden bazıları şunlardır:

“...Ucuz sosyal konutlarn olması gerek, belli bir müddet insanlar kendilerini toparlayana kadar."... (V.40)

"...Devletin ucuz kiralık konut sağlaması gerekli." ...(T.47)

"... Biz kiralanabilecek ucuz konut istiyoruz."... (S.66)

Katılımcıların önerileri doğrultusunda sosyal hizmet uzmanları evsizlik sorunu yaşayanların savunuculuklarının yapılması, dezavantajlı konumda bulunanların sağlıklı, sosyal ve ucuz konuta erişimlerinin sağlanmasına yönelik sosyal politikaların yapılandırılmasına katkı sağlamaları (Reamer, 1989) makro ölçekte önemli sosyal hizmet uygulamaları içerisinde yer almaktadır. Avustralya Sosyal Hizmet Uzmanları Derneği (2019)'ne göre; sosyal hizmet insanların evsizlik durumundan uygun fiyatlı sürdürülebilir konutlara geçmelerine yardımcı olabilecek programların oluşturulmasında da etkin görev almaktadırlar (The Australian Association of Social Workers, 2019). Bu bağlamda Türkiye' de önemli bir sosyal sorun olarak gün geçtikçe önem kazanan evsizlik sorununun çözümlenmesine dönük politikalara, programlara ve sosyal hizmet uygulamalarına ihtiyaç duyulmaktadır. Sosyal hizmet uzmanları evsizliğe yol açabilecek sosyo-ekonomik açıdan dengenin kaybedilmesine yol açabilecek sağlıksız düşünme biçimlerini değiştirmelerinde, bireylere ve ailelere ev ekonomisi yönetimlerinde gerekli olan bilgi ve becerinin kazandırılmasında etkin rol alabilirler. Sosyal hizmet uzmanları evsizlik riski ile karşı karşıya kalan bireylerin ve ailelerin belirlenmesinde, değerlendirmelerin yapılmasında, ucuz sosyal konutlara geçişlerinin sağlanmasında danışmanlık sunabilirler.

\section{SONUÇ ve ÖNERILER}

Kadın evsizliğini görünür kılarak sorunları, gereksinimleri ve çözüm önerilerini evsiz kadınların anlatıları ile şekillendirmeye olanak tanıyan bu çalışma sonucunda evsizlik sorunundan 
etkilenen kadınların demografik özellikler bakımından çeşitlilik gösterdiği, kadın evsizliğinin çeşitli sosyal sorun alanları ile (işsizlik, aile sorunları, şiddet, finansal kayıplar göçmen sorunları, eski hükümlü olma) ilişkili olduğu belirlenmiştir. Araştırma sonucunda evsizlik sorunu ile karşı karşıya kalan kadınların aynı zamanda işsizlik problemi ile de karşı karşıya bulundukları saptanmıştır. Bu bağlamda evsiz kadınlar için ilgi ve yetenekleri doğrultusunda sosyal güvenceli iş olanaklarının yaratılması gerekli görülmektedir. Evsizlik sorunu ile karşı karşıya kalan sokakta yaşayan ve barınma merkezlerinde kalan kadınların sosyal dışlanmalarının önüne geçebilmek için diğer dezavantajlı gruplarla (engelliler, sığınmacılar) ilgili olarak yapılan farkındalık çalışmalarında olduğu gibi evsizler ve kadın evsizliği ile ilgili olarak da yapılmasına gereksinim duyulmaktadır.

Çalışmadan elde edilen sonuçlar değerlendirildiğinde kadınların evsizlik sürecine geçme nedenleri farklılık göstermektedir. Söz konusu nedenlerin başında aile içi ilişki sorunları, göç öyküsü olan kadınların sosyal destek sisteminden yoksun bulunmaları ve ev kiralarının yüksek oluşu gelmektedir. Aile içi ilişki sorunlarının çözümlenebilmesi için evsiz kadınlara ve ailelerine yönelik aile refahını temel alan kadınları güçlendirmeye dayalı sosyal hizmet müdahalelerinin oluşturulması araştırma sonuçları itibari ile önemli görülmektedir. Bu bağlamda evsizlik süreci yaşayan kadınlar için barınma ihtiyacı ile birlikte diğer temel gereksinimlerin (beslenme, sağlık, güvenlik) karşılanarak biyopsikososyal yönden tam iyilik hali içinde olmalarını engelleyen sorunların çözümlenebilmesi ve evsizlik sürecinde yaşamı tehdit edebilecek risklerin ortadan kaldırılması ve kadınların güvenlik gereksinimlerinin giderilebilmesi için evsiz ve sosyal korunmadan yoksun olan kadınlara hizmet veren esnek yapıda kuruluşların oluşturulması, kadınlara sosyo-ekonomik ve psikososyal desteğin sağlanması gerekmektedir.

Araştırma sonucunda güvencesiz sosyal korunmadan yoksun olan başta kadınlar olmak üzere evsizlik sorunu ile karşı karşıya kalan dezavantajlı grupların konut ihtiyaçlarının çözümüne yönelik politikaların oluşturulması, bakım verdikleri çocukları ile birlikte yaşayabilecekleri geçici konut programlarının oluşturulması gerekmektedir.

Araştırma sonucunda evsizlik sorunu ile karşı karşıya kalan kadınlardan özellikle geldiği ülkesi farklı olanların sosyal medya aracılığı ile barınma merkezine başvurdukları saptanmıştır. Bu bağlamda evsizlik sorunu ile karşılaşma riski olan kadınlara hizmet verebilecek, kadınların mevcut olan toplumsal kaynaklara ulaşmalarını kolaylaştıracak sosyal medya ağının oluşturulmasına dönük programların yapılandırılması gerekmektedir.

\section{KAYNAKÇA}

Abraham, M. (2000). Isolation as a form of marital violence: The South Asian immigrant experience. Journal of Social Distress and the Homeless, 9(3): 221-236.

AHAR (United States Department of Housing and Urban Development). (2015). The 2015 Annual Homeless Assessment Report (AHAR) to Congress. The U.S. Department of Housing and Urban Development Office of Community Planning and Development. https://www.huduser.gov/portal/sites/default/files/pdf/2015-AHAR-Part-2.pdf (çevrimiçi). Erişim Tarihi: 10.03 .2020

Asgary, R., Alcabes, A., Feldman, R., Garland, V., Naderi, R., Ogedegbe, G., and Sckell, B. (2016). Cervical cancer screening cmong homeless women of New York City shelters. Maternal and Child Health Journal, 20(6): 1143-1150. DOI:10.1007/s10995-015-1900-1 
Baker, C.K., Cook, S.L., and Norris, F.H. (2003). Domestic violence and housing problems: a contextual analysis of women's help-seeking, received informal support, and formal system response. Violence Against Women, 9(7): 754-783. DOI: 10.1177/1077801203253402

Bassuk, E.L., Buckner, J.C., Perloff, J.N., and Bassuk, S.S. (1998). Prevalence of mental health and substance use disorders among homeless and low-income housed mothers. American Journal of Psychiatry, 155(11): 1561-1564.

Baxter, S. (1991). Under The Viaduct: Homeless in Beautiful B.C. Vancouver: New Star.

Baxter, E., and Hopper, K. (1981). Private Lives/Public Spaces Homeless Adults on the Streets of New York City. New York: Community Service Society.

Belcher, J.R., Greene, J.A., McAlpine, C., and Ball, K. (2001). Considering Pathways into Homelessness: Mothers, Addictions, and Trauma. Journal of Addictions Nursing, 13: 3-4, 199-208, DOI: $10.3109 / 10884600109052654$

Berzoff, J. (2013). Group therapy with homeless women. Smith College Studies in Social Work, 83(23):233-248. DOI:10.1080/00377317.2013.802967

Browne, A. (1993). Family violence and homelessness: The relevance of trauma histories in the lives of homeless women. American Journal of Orthopsychiatry, 63(3): 370-384. DOI:10.1037/h0079444

Busch-Geertsema, V., Edgar, W., O'Sullivan, E., and Pleace, N. (2010). Homelessness and Homeless Policies in Europa: Lessons from Research. FEANTSA, European Consensus Conference on Homelessness. Brussels: FEANTSA

Caton, C.L.M., El-Bassel, N., Gelman, A., Barrow, S., Herman, D., Hsu, E., Tochterman, A.Z., Johnson, K., and Felix, A. (2012). Rates and Correlates of HIV and STI Infection Among Homeless Women. AIDS and Behavior, 17(3): 856-864. DOI:10.1007/s10461-012-0198-x

Chambers, C., Chiu, S., Scott, A. N., Tolomiczenko, G., Redelmeier, D. A., Levinson, W., and Hwang, S. W. (2013). Factors associated with poor mental health status among homeless women with and without dependent children. Community Mental Health Journal, 50(5): 553-559. DOI:10.1007/s10597-013-9605-7

Coston, C. (1989). The original designer label: Prototypes of New York City's shopping-bag ladies. Deviant Behavior, 10(2): 157-172. DOI: 10.1080/01639625.1989.9967808

Creswell, J.W. (2016). Nitel Araştırma Yöntemleri Beş Yaklaşıma Göre Nitel Araştırma ve Araştırma Deseni (3. Baskı). Ankara: Siyasal Kitabevi.

Fellin, P., and Brown, K.S. (1989). Application of homelessness to teaching social work foundation content. Journal of Teaching in Social Work, 3(1): 17-33. DOI: 10.1300/j067v03n01_03

Goodman, L., Fels, K., and Glenn, C. (2006). No Safe Place: Sexual Assault in the Lives of Homeless Women. Applied Research Forum. National Online Resource Center on Violence Against Women. (ss.1-13). https://vawnet.org/sites/default/files/materials/files/201609/AR_SAHomelessness.pdf (çevrimiçi). Erişim Tarihi: 10.06.2020

Greifenhagen, A., and Fichter, M. (1997). Mental illness in homeless women: an epidemiological study in Munich Germany. Eur Arch Psychiatry Clin Neurosci, 247:162-172.

Hatty, S.E. (1996). The violence of displacement: The problematics of survival for homeless young women. Violence Against Women, 2(4): 412-428. DOI: 10.1177/1077801296002004005 
Heslin, K., Robinson, P. L., Baker, R. S., and Gelberg, L. (2007). Community characteristics and violence against homeless women in Los Angeles County. Journal of Health Care for the Poor and Undeserved, 18(1): 203-218. DOI: 10.1353/hpu.2007.0011

Işıkhan, V. (2002). Kentlerin Gölgesinde Yaşayan Evsizler. Ankara: Kardelen Ofset.

Jasinski, J.L., Wesely, J.K., Mustaine, E., and Wright, J. D. (2005). The Experience of Violence in the Lives of Homeless Women: A Research Report. U.S. Department of Justice, 1-101. https://www.ojp.gov/pdffiles1/nij/grants/211976.pdf (çevrimiçi). Erişim Tarihi:10.04.2020

Johnson, A.K., and Cnaan, R.A. (1995). Social Work Practice with Homeless Persons: State of the Art. Research on Social Work Practice, 5(3): 340-382. DOI:10.1177/104973159500500306

Kaya-Kılıç, A., and Aslantürk, H. (2019). Socio-demographic Characteristics of Homeless People and Their Experiences of Living on the Streets: Antalya Sample. Journal of Society \& Social Work, 30(2): 417-437.

Krupnick, J.L., Green, B. L., Stockton, P., Miranda, J., Krause, E., and Mete, M. (2008). Group interpersonal psychotherapy for low-income women with PTSD. Psychother Res., 18(5):497-507. DOI: $10.1080 / 10503300802183678$.

Kennedy, A.C., Bybee, D., and Greeson, M.R. (2015). Intimate partner violence and homelessness as mediators of the effects of cumulative childhood victimization clusters on adolescent mothers' depression symptoms. Journal of Family Violence, 30(5), 579-590. DOI:10.1007/s10896-015-9689-7

Kleiman, S. (2004). Phenomenology: To Wonder and Search for Meanings. Nurse Researcher, 11(4), 7-19. https://doi.org/10.7748/nr2004.07.11.4.7.c6211.

Lam, J.A., and Rosenheck, R. (1998). The effect of victimization on clinical outcomes of homeless persons with serious mental illness. Psychiatric Services, 49(5): 678-683.

Lee, B.A., and Price-Spratlen, T. (2004). The geography of homelessness in American communities: Concentration or dispersion?. City \& Community, 3(1): 3-27. DOI:10.1111/j.15356841.2004.00064.x

Lenon, S. (2000). Living on the edge: Women, poverty and homelessness in Canada. Canadian Woman Studies, 20 (3): 123-127.

MacKenzie, D., Desmond, K., and Steen, A. (2007). Household Organisational Management Expenses Advice Program Evaluation Report 2007. Australian Government Department of Families, Housing, Community Services and Indigenous Affairs. Commonwealth of Australia: Canberra.

Magee, M., and Huriaux, E. (2008). Ladies' night: Evaluating a drop-in program for homeless women housed in San Francisco's Mission District. International Journal of Drug Policy, 19(2): 11321. DOI: 10.1016/j.drugpo.2007.11.009.

Marpsat, M. (2000). An Advantage with Limits: The Lower Risk for Women of becoming Homeless. In: Population, an English selection, $12^{\mathrm{e}}$ année, $\mathrm{n}^{\circ} 1,2000$. (ss. 247-291). https://www.persee.fr/doc/pop_0032-4663_2000_hos_12_1_7089 (çevrimiçi). Erişim Tarihi: 12.07.2020.

Marston, G. and Shevellar, L. (2010). The experience of using fringe lenders in Queensland: A pilot study. Social Policy Unit, The University of Queensland- School of Social Work \& Human Services_Social Policy Unit.

Moustakas, C. (1994). Phenomenological research methods. Thousand Oaks, CA: Sage. 
Muñoz, M., Crespo, M., and Perez-Santos, E. (2005). Homelessness effects on men's and women's health. International Journal of Mental Health, 34(2):47-61. DOI:10.1080/00207411.2005.11043400

Murray, S. (2011). Violence against homeless women: Safety and social policy. Australian Social Work, 64(3): 346-360. DOI:10.1080/0312407x.2011.552983

National Association of Social Workers (NASW). (2015). Code of Ethics. Washington, DC: Author. Retrieved from https://www.socialworkers.org/About/Ethics/Code-of-Ethics.aspx

Olufemi, O. (2000). Feminisation of poverty among the street homeless women in South Africa. Development Southern Africa, 17(2): 221-234. DOI:10.1080/713661399

Poremski, D., Distasio, J., Hwang, S. W., and Latimer, E. (2015). Employment and income of people who experience mental illness and homelessness in a large Canadian sample. The Canadian Journal of Psychiatry, 60(9): 379-385. DOI:10.1177/070674371506000902

Ravenhill, M. (2008). The Culture of Homelessness. Hampshire: Ashgate Publishing.

Reamer, Frederic G. (1989). The Affordable Housing Crisis and Social Work. Faculty Publications. Paper 169.

Romaszko, J., Cymes, I., Dragańska, E., Kuchta, R., and Glińska-Lewczuk, K. (2017). Mortality among the homeless: Causes and meteorological relationships. Plos One, 12(12):1-16. DOI: 10.1371/journal.pone.0189938

Rosa, A.S., and Bretas, A.C.P. (2015). Violence in the lives of homeless women in the city of São Paulo, Brazil. Comunıcação Saúde Educação,19(53): 275-285.DOI: 10.1590/1807-57622014.0221

Rossi, P.H. (1991). Down and out in America: The origins of homelessness. Chicago: University of Chicago Press.

Schmidt, R., Hrenchuk, C., Bopp, J. and Poole, N. (2015). Trajectories of women's homelessness in Canada's 3 northern territories. International Journal of Circumpolar Health, 74(1): 297-78. DOI: 10.3402/ijch.v74.29778

Sinha, M. (2013). Family violence in Canada: A statistical profile, 2011. Canada: Component of Statistics Canada catalogue no. 85-002-X Juristat.

Shinn, M., and Khadduri, J. (2020). Homelessness and What to Do About It. In the Midst of Plenty. John Wiley \& Sons Ltd. ss. 248.

Sikich, K.W. (2008). Global female homelessness: A multi-faceted problem. Gender Issues, 25(3): 147-156. DOI:10.1007/s12147-008-9062-8

Smith, E.M., and North, C.S. (1994). Not all homeless women are alike: Effects of motherhood and the presence of children. Community Mental Health Journal, 30(6): 601-610.

Smith, J. A. (2004). Reflecting on the development of interpretative phenomenological analysis and its contribution to qualitative research in psychology. Qualitative research in psychology, $1(1), 39-54$.

Tekindal, M. ve Uğuz Arsu, Ş. (2020). Nitel araştırma yöntemi olarak fenomenolojik yaklaşımın kapsamı ve sürecine yönelik bir derleme. Ufkun Ötesi Bilim Dergisi, 20 (1), 153- 182.

Tessler, R., Rosenheck, R., and Gamache, G. (2001). Gender differences in self-reported reasons for homelessness. Journal of Social Distress and the Homeless, 10(3): 243-254. DOI:10.1023/a:101668870769 
The Australian Association of Social Workers' (AASW). (2019). Of Social Work Practice: Homelessness. https://www.aasw.asn.au/document/item/12225 (çevrimiçi). Erişim Tarihi: 14.03.2020

Thomas, T.N. (1995). Acculturative stress in the adjustment of immigrant families. Journal of Social Distress and the Homeless, 4(2): 131-142. DOI: 10.1007/bf02094613

Tyler, K. A., Hoyt, D. R., Whitbeck, L. B., and Cauce, A. M. (2001). The effects of a high-risk environment on the sexual victimization of homeless and runaway youth. Violence and Victims, 16(4): 441-455.

Waldbrook, N. (2013). Formerly homeless, older women's experiences with health, housing, and aging, Journal of Women \& Aging, 25(4): 337-357. DOI: 10.1080/08952841.2013.816213

Weinreb, L., Goldberg, R., and Perloff, J. (1998). Health characteristics and medical service use patterns of sheltered homeless and low-income housed mothers. Journal of General Internal Medicine, 13(6): 389-397. DOI:10.1046/j.1525-1497.1998.00119.x

Weinreb, L., Perloff, J., Goldberg, R., Lessard, D., and Hosmer, D. W. (2006). Factors associated with health service utilization patterns in low-income women. Journal of Health Care for the Poor and Underserved, 17(1): 180-199. DOI: 10.1353/hpu.2006.0036

Wenzel, S.L., Koegel, P.A., and Gelberg, L. (2000). Antecedents of physical and sexual victimisation among homeless women: A comparison to homeless men. American Journal of Community Psychology, 28, 367-390. DOI: 10.1023/A:1005157405618.

White, B. M., \& Newman, S. D. (2014). Access to primary care services among the homeless. Journal of Primary Care \& Community Health, 6(2): 77-87. DOI: 10.1177/2150131914556122

Wisner, B. (1998). Marginality and vulnerability. Applied Geography, 18 (1): 25-33.

Yates, J. (2007). Housing affordability and financial stress, Australian Housing and Urban Research Institute, Sydney Research Centre, Research Paper No 6.

Zlotnick, C., and Zerger, S. (2009). Survey findings on characteristics and health status of clients treated by the federally funded (US) Health Care for the Homeless Programs. Health and Social Care Community, 17 (1): 18-26. DOI: 10.1111/j.1365-2524.2008.00793.x 